\title{
DEBATES
}

\section{"É preciso dar um passo atrás, para avançar dois": Ellen Wood e o retorno à teoria política contra a armadilha das análises fragmentárias}

\author{
"It takes a step back, then two steps forward": Ellen Wood and the \\ return to political theory against the trap of fragmentary analysis
}

\section{Jefferson Ferreira Nascimento}

\section{Resumo}

O artigo analisa a obra de Ellen Wood para compreender como a "retirada" da centralidade da classe como categoria unificadora da experiência humana afeta o confronto ao esvaziamento da democracia. A dinâmica consiste em esclarecer a proposta de Democracia Substantiva. Depois, discutir a importância da redefiniçáo do conceito de classe para pensar o mundo atual. Por fim, avaliar obstáculos práticos que se constituem entraves teóricos para superar a "recessão do marxismo". $\mathrm{O}$ argumento está ancorado na defesa da teoria política como "exercício de persuasão" baseado em problemas reais que o autor busca responder e superar. Como resultado, destaca-se a busca por depurar uma teoria política da obra de Wood e, para isso, compreende-se que: (1) não é possível uma Democracia Substantiva no capitalismo, dada a separação entre o "político" e o "econômico"; (2) urge compreender, antes, a luta de classes local e nacionalmente para possibilitar estratégias de desenvolvimento nacionais autônomas.

\section{Palavras-chave}

Classe Social; Democracia; Teoria Política.

\section{Abstract}

This paper analyzes Ellen Wood's work to understand how the "retreat" from the centrality of the class as a unifying category of human experience affects the possibility of facing the substantial emptying of democracy. The dynamic is to clarify the proposal of Substantive Democracy. After, to discuss the importance of redefining the concept of social class to think about the world today. Lastly, to assess practical obstacles that constitute theoretical obstacles to overcoming the "recession of Marxism". The argument is anchored in the defense of political theory as an "exercise of persuasion" based on real problems that the author seeks to answer and overcome. As a result, we highlight the search for a political theory of Wood's work and, for this, it is understood that: (1) Substantive Democracy is not possible in capitalism, marked by the separation of political and economic; (2) it is necessary to understand the class struggle, first, locally and nationally to confront dependency and enable autonomous national development strategies.

\section{Keywords}

Social Class; Democracy; Political Theory. 


\section{Introdução ${ }^{1}$}

Em reação à crise de 2008, o Federal Reserve (FED) e o Tesouro dos Estados Unidos nacionalizaram a seguradora AIG por US\$ 180 bilhões; o Tesouro assumiu os maiores bancos em hipotecas imobiliárias (Fannie Mae e Freddie Mac) por US\$100 bilhôes cada, auxiliou o Bank of America na aquisiçáo do banco de investimentos Merryl Linch e preparou um plano de US\$ 700 bilhões para socorrer bancos com ativos desvalorizados. Além disso, George W. Bush anunciou US\$ 250 bilhões para recapitalizar os principais bancos. Ao mesmo tempo, a crise provocou o confisco de milhôes de residências hipotecadas, a desvalorização dos imóveis e a falta de crédito empresarial e individual, gerando menos demanda, menos incentivos para produção e elevados índices de desemprego. Do mesmo modo, no Brasil, no contexto da crise de 2015-17, foi aprovado um REFIS (refinanciamento de tributos) para empresas e incentivos financeiros à multinacionais do petróleo por 20 anos com custo anual aproximado de R\$ 40 bilhôes e o Conselho Administrativo de Recursos Fiscais (CARF) isentou R \$ 25 bilhões em tributos do Itaú. Além da Reforma Trabalhista e da Emenda do Teto de Gastos. Ou seja, novamente, recursos públicos foram usados para socializar dívidas privadas, atendendo aos desígnios do mercado em detrimento das necessidades da população.

Tais acontecimentos ilustram que a democracia, nas sociedades capitalistas, só pode ser assim definida, segundo Ellen Meiksins Wood, devido à "separação e [a]o isolamento da esfera econômica e sua invulnerabilidade ao poder democrático". Assim, por vezes, a democracia é invocada "em defesa da redução de direitos democráticos em outras partes da 'sociedade civil' ou do domínio político, se isso for necessário para proteger a propriedade e o mercado contra o poder democrático" (WOOD, 2011b, p. 202).

Wood argumenta que "a apropriação do excedente de trabalho ocorre na esfera 'econômica' por meios 'econômicos'”. Isto significa que a mais-valia é extraída pela "separação completa do produtor das condiçóes de trabalho e pela propriedade privada absoluta dos meios de produção pelo apropriador". Em outras palavras, "as funçôes sociais de produção e distribuição, extração e apropriação de excedentes, e a

\footnotetext{
${ }^{1}$ Este artigo nasce da dissertação "A redefinição do conceito de classe e suas implicaçóes políticas: uma análise sobre Ellen Meiksins Wood", defendida em 2018, no PPGCS da UNIOESTE - Campus Toledo, orientada por Dr. Osmir Dombrowski. Incorpora as contribuiçóes recebidas na apresentação do paper "A redefinição do conceito e do papel político da Classe Social e a questão da Democracia em Ellen M. Wood", no GT 31 - Teoria Política e Pensamento Político Brasileiro, do 41. Encontro Anual da ANPOCS, em 2017.
} 
alocação do trabalho social são, de certa forma, privatizadas e obtidas por meios não autoritários e não políticos". Apesar disto, o Estado cumpre papel fundamental na garantia da propriedade privada absoluta e na apropriação da mais-valia, pois "a esfera econômica se apoia firmemente na política". Em síntese, "a diferenciação do econômico e do político no capitalismo é mais precisamente a diferenciação das funçóes políticas e sua alocação separada para a esfera econômica privada e para a esfera pública do Estado" (WOOD, 2011b, p. 34-36).

Como agravante, nas últimas décadas, o movimento operário e, particularmente, as organizaçóes sindicais foram atingidos pela flexibilização das relações de trabalho, pelo desemprego estrutural, pela subcontratação, pela redução do emprego industrial, pela possibilidade do deslocamento e segmentação da atividade da empresa, pelas novas formas de gestão de pessoas nas empresas que discursivamente evocam a colaboração e pelo abandono da proteção social em favor de uma lógica baseada na competitividade (SANTANA e RAMALHO, 2010).

Essas mudanças foram acompanhadas por um crescente movimento teóricoanalítico, supostamente de esquerda, cujo programa se baseia "na autonomização da ideologia e da política de toda base social, sobretudo, de toda base classista" (WOOD, 1998, p. 2, tradução nossa). Em reação, este artigo analisa a obra de Ellen Wood buscando compreender: como a "retirada" da centralidade da classe como categoria unificadora da experiência humana, ancorada em análises fragmentárias da realidade, afeta a possibilidade de enfrentar ao esvaziamento substancial dos regimes democráticos.

Por um lado, a cidadania não é determinada pela condição socioeconômica, por outro, a igualdade cívica nas democracias contemporâneas não impacta sobre a desigualdade de classe. Deste modo, a partir de insights e sugestôes elaboradas por Edward Palmer Thompson, Ellen Wood propóe analisar a relevância da política como instrumento de dominação social e o lugar dos conflitos, especificamente políticos, nos processos de transição entre os diferentes modos de produção e na superação da dominação de classe.

Cumpre considerar que a teoria política é um modo de engajamento na luta política. Em consonância, para Ellen Wood, “o ideal humano² proposto e defendido

\footnotetext{
${ }^{2}$ Não confundir com natureza humana. Segundo Neal Wood, ambos se relacionam, pois, "o teórico, ao postular o que os humanos são capazes de se tornar, também está fazendo certas suposições sobre sua essência". Porém, o ideal humano "implica uma ética social e um contexto político mais propício para formação e florescimento de tal indivíduo” (WOOD, 2002, p. 53).
} 
pelos filósofos nos diz muito sobre quais eram seus compromissos sociais e políticos e que posição defendiam nos conflitos que marcaram suas épocas" (WOOD, 2011a, p. 20, tradução nossa).

O artigo possui a seguinte dinâmica. Primeiro, a temática da Democracia Substantiva ${ }^{3}$ na obra de Ellen Wood apresentada como o norte de sua proposição. Segundo, a discussão acerca da importância da redefinição do conceito de classe social para pensar o mundo atual. Terceiro, os obstáculos práticos que se constituem entraves teóricos para a superação da "recessão do marxismo", notadamente a questão das identidades sociais e as desigualdades entre as formaçóes sociais capitalistas.

Assim, o intento é reagir à "divisão estéril" da ciência política, entre a "real ciência política, clamando lidar cientificamente com os fatos da vida política como eles são", e a "teoria confinada na torre de marfim da filosofia política e refletindo não sobre o que é, mas sobre o que deveria ser” (WOOD, 2011a, p. 17, traduçáo nossa).

Como resultado, destacamos três questôes. Primeiro, no capitalismo não é possível uma democracia substantiva, entendida como poder pelo demos, que garanta a isegoria, autodeterminação dos produtores e a "liberdade de livre associação" Segundo, não é possível pensar em estratégias de desenvolvimento nacionais e autônomas nos quadros da dependência. A economia mundial é articulada em fortes elos de dependência na qual as metrópoles se alimentam da exploração de seus satélites. Nesse contexto, cabe destacar a proposta de Gunder Frank de uma "guerra de guerrilhas", começando no enfrentamento da burguesia nacional (GUNDER FRANK, 2016, p. 395). Finalmente, a realização da Democracia Substantiva e a ruptura da situação de dependência necessitam da luta de classes. E é aí que a obra de Wood precisa ser resgatada, afinal, temos alguns imperativos: (a) "recalibrar" o conceito de classe para compreender a luta de classes hoje; e (b) tal como sua concepção política defende, é preciso entender os subsídios deixados pelos clássicos, reconhecendo a importância de mediaçóes necessárias e possíveis para pensar a atual

\footnotetext{
${ }^{3}$ Democracia Substantiva é "o governo pelo povo ou pelo poder do povo" que possibilita a "reversão do governo de classe, em que o demos, o homem comum, desafia a dominação dos ricos”. Porém, o capitalismo não subsiste caso "a vontade do povo tenha precedência sobre os imperativos dos lucros e da acumulação". Por isso, "a democratização deve seguir pari passu com a 'destransformação em mercadoria', o que significaria o fim do capitalismo” (WOOD, 2011b, p. 7-8).

${ }^{4}$ A redundância ressalta a diferença entre o ideal dessa liberdade efetiva e a liberdade formal de associação existente nas democracias representativas. No texto original, o termo é freedom of the free association.
} 
dinâmica da luta de classes. Desse modo, afirma-se o desafio, depurar de sua obra uma teoria política que reflita sobre a realidade como totalidade sistêmica e proponha caminhos para o enfrentamento.

\section{A Democracia Substantiva como o norte}

Como marxista, Ellen Wood conserva como ideal "a realização do potencial físico e mental do indivíduo", reafirma a "efetivação desses poderes criativos, mas o contexto social radicalmente transformado que acabaria com a alienação humana" é tanto a superação da exploração do homem pelo homem, quanto - e não menos importante - o reconhecimento de uma forma política substancialmente democrática (WOOD, 1983, 1988 e 2011b). ${ }^{5}$

A autora propóe uma democracia cujo poder decisório esteja no demos, assegurando, efetivamente, a isegoria, garantindo a autodeterminação dos produtores pelo exercício do poder político e pela "liberdade de livre associação" (WOOD, 2011 b, p. 248). A proposta parte da constatação da insuficiência das democracias representativas, que garantem o direito à representação e não o exercício do poder político aos cidadãos.

Em Democracia contra Capitalismo, Wood defende que a luta pela democracia pode unificar e mobilizar diversas vertentes de lutas populares. Porém, uma democracia substantiva não é possível no capitalismo. Daí a proposta de renovação do materialismo histórico visando à Democracia Substantiva no socialismo. Essa renovação passa pela retomada do espírito crítico do marxismo, pela compreensão da centralidade da luta política e pelo abandono dos elementos particularistas da luta sociopolítica contemporânea:

Não existe capitalismo governado pelo poder popular, não há capitalismo em que a vontade do povo tenha precedência sobre os imperativos do lucro e da acumulação, não há capitalismo em que as exigências de maximização dos lucros não definam as condiçóes mais básicas de vida

\footnotetext{
${ }^{5} \mathrm{O}$ ideal humano para Marx e Engels, de acordo com Neal Wood, é “a realização do potencial físico e mental do indivíduo e na efetivaçáo desses poderes criativos dentro de um contexto social radicalmente transformado que acabaria com a alienação humana e a exploração do homem pelo homem" (WOOD, 2002, p. 55, tradução nossa).
} 
[...] o capitalismo coloca necessariamente mais e mais esferas da vida fora do alcance da responsabilidade democrática (WOOD, 2011b, p. 8).

Urge, portanto, compreender a totalidade sistêmica do capitalismo e evitar determinismos, como o economicismo e os novos revisionismos - pós-marxismos, pós-modernismos, etc. ${ }^{6}$-, para garantir, ao mesmo tempo, as liberdades civis básicas e o "governo pelo povo" ou "pelo poder do povo", pois "nunca houve uma sociedade capitalista em que a riqueza não tivesse acesso privilegiado ao poder" (WOOD, 2011b, p. 8).

Estamos diante da "separação da condição cívica da situação de classe", que é resultado da separação entre o "econômico" e o "político" no capitalismo (WOOD, 2011b, p. 173). Por isso, é imperioso explicar "como e em que sentido o capitalismo enfiou uma cunha entre o econômico e político". Neste intento, Marx, a partir da crítica à economia política, teria "o propósito de revelar a face política da economia que havia sido obscurecida pelos economistas políticos clássicos" (WOOD, 2011b, p. 28). Assim:

[...] o segredo fundamental da produção capitalista revelado por Marx [...] refere-se às relaçóes sociais e à disposição de poder que se estabelecem entre os operários e o capitalista para quem vendem sua força de trabalho [...] a disposição de poder entre o capitalista e o trabalhador tem como condição a configuração política do conjunto da sociedade [...] o "pontode-partida" da produção capitalista 'não é outra coisa senão o processo histórico de isolar o produtor dos meios de produçáo', um processo de luta de classes e de intervenção coercitiva do Estado em favor da classe apropriadora. A própria estrutura do argumento sugere que, para Marx, o segredo último da produção capitalista é político (WOOD, 2011b, p. 28 , grifo da autora).

Darlan Montenegro (2012), analisando Wood, explica que a separação das esferas política e econômica se apresenta como realidade e dissimulação. Realmente, a esfera econômica no capitalismo está separada do Estado. Mas, a origem das

\footnotetext{
${ }^{6}$ Para a autora, o "pós-marxismo deu lugar ao culto do pós-modernismo e a seus princípios de contingência, fragmentação e heterogeneidade, sua hostilidade a qualquer noção de totalidade, sistema, estruturas, processos e grandes narrativas". Além disto, a "fragmentação e contingência dos pós modernistas se unem à estranha aliança com a 'grande narrativa do fim da história”" (WOOD, 2011b, p. 13).
} 
instituições liberais que compõem a sociedade civil é camuflada, ocultando que, para construir essa separação, o Estado foi tomado pela burguesia. Ou seja,

[...] a alocação social de recursos e de trabalho não ocorre por comando político, por determinação comunitária, por hereditariedade, costumes nem por obrigação religiosa, mas pelos mecanismos de intercâmbio de mercadorias. Os poderes de apropriação de mais-valia e de exploração não se baseiam diretamente nas relações de dependência jurídica ou política, mas sim numa relação contratual entre produtores 'livres' juridicamente livres e livres dos meios de produção - e um apropriador que tem a propriedade privada absoluta dos meios de produção [...] A propriedade privada absoluta dos meios de produção, a relação contratual que prende o produtor ao apropriador, o processo de troca das mercadorias exigem formas legais, aparato de coação e as funçôes policiais do Estado (WOOD, 2011b, p. 35).

Por um lado, “a economia tem suas próprias formas jurídicas e políticas” com finalidade exclusivamente "econômica", por outro, temos uma esfera pública especializada cuja "autonomia do Estado capitalista está inseparavelmente ligada à liberdade jurídica e à igualdade entre os seres livres". Portanto, "apropriação e coação" são dois momentos da apropriação capitalista (WOOD, 2011b, p. 35-36). Em outros termos:

[...] de um lado, o Estado 'relativamente autônomo' tem o monopólio da força coercitiva; do outro, essa força sustenta o poder 'econômico' privado que investe a propriedade capitalista da autoridade de organizar a produção [...] Embora o poder 'econômico' de apropriação possuído pelo capitalista esteja separado dos instrumentos de coaçấo política que impóem, esse poder de apropriação está mais do que nunca direta e intimamente integrado com a autoridade de organizar a produção (WOOD, 2011b, p. 36).

Essa separação se efetiva após lutas em ambas as esferas decididas na esfera política graças à intervenção violenta do Estado em favor da classe apropriadora.7 Isto

\footnotetext{
${ }^{7}$ Em um período de crise do capital, a dissimulação dessa posição é arrefecida. A restrição de direitos a partir da Reforma Trabalhista e a intensificação do debate sobre considerar os movimentos sociais como agrupamentos terroristas revela com clareza como a "esfera política", por meio do Estado, age para decidir a luta de classes em favor da "apropriação privada” em detrimento dos "deveres públicos".
} 
é, diferente das formas pré-capitalistas, no capitalismo ocorre "uma separação completa entre a apropriaçáo privada e os deveres públicos; resultando no desenvolvimento de uma nova esfera de poder inteiramente dedicado aos fins privados, e não aos sociais" (WOOD, 2011b, p. 36).

De Locke a Benjamim Constant, os liberais defendiam restringir aos proprietários as liberdades típicas do senhorio, limitando o acesso à cidadania. Entretanto, a partir da obra $O$ Federalista (Federalist Papers) ${ }^{8}$ e da descriçáo feita por Tocqueville sobre os Estados Unidos, podemos perceber que o esforço não era mais restringir o acesso, mas reduzir o poder da condiçáo civil. É assim que a cidadania passa a ser cada vez mais inclusiva - abolição da escravidão, inclusão das mulheres, etc. - e menos poderosa (MONTENEGRO, 2012).

Mais inclusiva, pois o liberalismo, uma ideia moderna construída sobre princípios pré-modernos e pré-capitalistas, só pôde se fundir à democracia devido às "relações sociais específicas do capitalismo", marcadas pela separação do "político" em relação ao "econômico" (WOOD, 2011b, p. 23). Mas, menos poderosa de que maneira?

A condição cívica na democracia contemporânea consiste no gozo dos direitos políticos e civis, excluindo aqueles poderes políticos necessários à apropriação da mais-valia, que são exclusivos dos proprietários. Há uma diferenciação das funções políticas: as de gestão pública pelo Estado e as funçôes intocadas no "econômico" exclusivas da propriedade privada. Quanto mais livres, jurídica e politicamente, mais alienados são os trabalhadores da posse dos meios de produção: a cidadania é universalizada, mas não limita a exploração do trabalho, pois os poderes políticos que garantem a apropriação da mais-valia se encontram na propriedade privada. Assim, na democracia representativa, o trabalhador é despossuído e alienado dos meios de produção sem ser livre dos imperativos do mercado.

Em outras palavras, a liberdade dos proprietários foi assegurada em uma democracia formal cuja liberdade e a igualdade jurídica são garantidas. Contudo, os bens extraeconômicos não atingem as relaçôes contratuais de produção entre trabalhadores e apropriadores (MONTENEGRO, 2012) $)^{9}$. As lutas econômicas no

\footnotetext{
${ }^{8}$ Ellen Wood menciona mais diretamente os escritos de Alexander Hamilton no Federalist n. 35 e os escritos de James Madison no Federalist n. 10, relacionando essas teses às concepçóes de Sir Thomas Smith que associava a "multidão trabalhadora" às "pessoas inferiores" que devem "buscar em seus superiores sociais a sua própria voz política” (WOOD, 2011b, p. 186-187).

9 A "separação completa entre a apropriação privada e os deveres públicos" não advém da concepção original de democracia. Em Atenas, a democracia, como poder do demos, não incluía a separação entre
} 
espaço da produção identificam o local da apropriação ${ }^{10}$, mas são insuficientes para a emancipação. Tal como a luta política que se concentra apenas no Estado, sem identificar as funçôes políticas intocadas na esfera econômica, também tem pouca chance de êxito na construção de uma democracia substantiva. A proposta é a "liberdade de livre associação" para organizar democraticamente a produção, entendendo que o capitalismo é um modo de produção dotado de especificidade histórica.

\section{Classe como processo e relação}

Nas últimas décadas, assistimos, inclusive nas análises políticas, o gradual abandono de teorias de alcance estrutural, como alertava Gildo Marçal Brandão:

[...] chega a ser constrangedor observar o esforço que se faz para tentar esquecer que a fonte mais comum e duradoura dos conflitos e dos processos políticos continua a ser aquilo que Madison chamou de 'distribuição variada e desigual da propriedade', e que a exploração dessas formas institucionais de 'dependência do político diante do econômico tem sido o objeto, não o programa', de qualquer teoria crítica digna de seu nome. Por isso mesmo, se estamos condenados a tomar os processos políticos como variáveis independentes, não há como não denunciar a provisoriedade dessa operação (BRANDÁO, 1998, s.p.).

Em sentido contrário, Ellen Wood e Robert Brenner ${ }^{11}$ formularam o Marxismo Político ${ }^{12}$ em consonância com o fato de que "a análise marxiana básica do

sociedade e Estado - havia a polis, os atenienses. A cidadania era restrita, mas garantia a todos os homens livres (camponeses, artesãos e grandes proprietários) a isegoria, salvaguardando o direito à autodeterminação no âmbito da produção aos trabalhadores. O desafio na proposta woodiana é universalizar essa garantia por meio da luta de classes, como não ocorria em Atenas (WOOD, 2011b, p. 36).

${ }^{10}$ No capitalismo, produção e apropriação coincidem totalmente.

${ }^{11}$ Historiador norte-americano que desenvolveu o Marxismo Político junto com Ellen Wood. Hoje é diretor do Centro de Teoria Social e História comparada da Universidade da Califórnia (UCLA), editor do jornal Against the Current e membro do comitê editorial da New Left Review.

12 Nasce em oposição ao estruturalismo, aos pós-marxismos, ao marxismo analítico e a outras vertentes, marxistas ou não, que negavam a "possibilidade da política revolucionária". Tem como principal influência o Grupo de Historiadores do Partido Comunista Britânico, com destaque para Thompson, "Hobsbawm, Rodney Hilton, Christopher Hill, George Rudé e outros”, visando à recuperação da luta 
desenvolvimento e do modus operandis do capitalismo conserva sua validade". Porém, "qualquer revivescência futura do interesse por Marx terá que basear-se, sem dúvida, em substanciais recalibragens das leituras tradicionais do seu pensamento" (HOBSBAWM, 2011, p. 356).

Buscando tais "recalibragens", Wood defendeu a necessidade de uma teoria de classes que respeite o espírito do texto marxiano ${ }^{13}$. A autora buscou uma concepção adequada à compreensão da realidade social contemporânea, respeitando os critérios definidos por Marx. Primeiro, há três principais classes: os assalariados (proprietários da força de trabalho), os capitalistas (detentores do capital) e os proprietários fundiários. Segundo, a compreensão de que uma classe vive basicamente de salário, enquanto outra vive do lucro que retorna de seu capital investido e a última da renda que sua propriedade fundiária proporciona (MARX, 2017, p. 947-948). Terceiro,

[...] a tendência constante e a lei de desenvolvimento do modo de produção capitalista consistem em separar cada vez mais do trabalho os meios de produção, bem como concentrar cada vez mais em grandes grupos os meios de produção que se encontravam dispersos, isto é, transformar o trabalho em assalariado e os meios de produção em capital. A essa tendência corresponde, por sua vez, a autonomização da propriedade fundiária da terra em propriedade fundiária correspondente ao modo de produção capitalista (MARX, 2017, p. 947).

Ellen Wood buscou uma análise embasada em uma teoria marxista que considerasse a separação do "político" e do "econômico". ${ }^{14}$ Quer dizer, devido ao comportamento dinâmico das relações de produções capitalistas, era preciso uma

de classes como elemento central da "dinâmica histórica" e, também, do papel central da classe trabalhadora na superação do capitalismo (SARTELLI, 2013, p. 8-9, tradução nossa)

${ }^{13}$ Marx e Engels não desenvolveram um vocabulário teórico rigoroso sobre o conceito. No terceiro livro d'O Capital, há o esboço de uma reflexão sobre classes sociais no curto e inacabado capítulo "As classes". Nele, a argumentação começa pelo "o que faz com que assalariados, capitalistas e proprietários da terra constituam as três grandes classes sociais?” Questão que Marx responde com o indicativo: a "identidade entre rendimentos e fontes de rendimento". O capítulo foi interrompido quando o autor começava a distinguir classe e fração de classe (MARX, 2017, p. 947- 948).

${ }_{14}$ Para aprofundar a questão, o primeiro capítulo da dissertaçấo indicada na nota número 1 elabora um percurso do desenvolvimento do conceito no marxismo, iniciando por Engels em A situação da classe trabalhadora na Inglaterra, passando pelas produçóes de Marx e de Marx e Engels, além de analisar o conceito em Lênin, Lukács, Gramsci e Poulantzas. 
concepção adequada para pensar a luta de classes em meio a fragmentação da vida social e a separação entre condição cívica e de classe. Para ela:

\begin{abstract}
[...] o modo de análise de Thompson permite reconhecer o papel ativo da classe trabalhadora, com sua cultura e valores, em sua própria "formação". Este papel pode ser obscurecido por formulaçóes que falam, por uma parte, do "agrupamento e transformação de objetivos da força de trabalho pela revolução industrial”, e por outra - sequencialmente "da subjetiva germinaçáo de uma cultura de classe em resposta a ela" (WOOD, 1983, s.p., tradução nossa).
\end{abstract}

Thompson, em A Formação da Classe Operária Inglesa, pretendia ressaltar o movimento de "autofazer-se" das classes sociais ao longo da história. Essa pretensão é prejudicada na tradução, pois “a palavra 'formação' perde em muito o conteúdo subjetivo e processual de 'making'", segundo a tradutora Denise Botman. Classe, para Thompson, é "um fenômeno histórico, que unifica uma série de acontecimentos díspares e aparentemente desconectados, tanto na matéria-prima da experiência como na consciência [...] [é] algo que ocorre efetivamente (e cuja ocorrência pode ser demonstrada) nas relações humanas" (THOMPSON, 1987, p. 9).

Ao enfatizar que a classe não é apenas uma "estrutura" ou "categoria" e que nem mesmo a "mais fina rede sociológica consegue oferecer um exemplar puro", Thompson alerta sobre o fato de que ela "estava presente no seu próprio fazer-se [...] [como resultado de] experiências comuns (herdadas ou partilhadas)". Ou seja, a experiência de classe é determinada, em grande medida, pelas relações de produção. Enquanto a "consciência de classe é a forma como essas experiências são tratadas em termos culturais: encarnadas em tradições, sistemas de valores, ideias e formas institucionais" (THOMPSON, 1987, p. 9-10).

Em A Miséria da Teoria, "experiência” é definida como "a resposta mental e emocional, seja de um indivíduo ou de um grupo social, a muitos acontecimentos inter-relacionados ou a muitas repetições do mesmo tipo de acontecimento". Portanto, a experiência sempre "acontece" em relação a algo, ela é mediada pela cultura e "acontece" porque os indivíduos refletem sobre o que vivenciam e os afetam. A experiência "surge espontaneamente no ser social [...] porque homens e mulheres - e não apenas os filósofos - são racionais e refletem sobre o que acontece a eles e ao seu mundo" (THOMPSON, 1981, p. 16). Por meio da experiência "a 
estrutura é transmutada em processo, e o sujeito é reinserido na história" (THOMPSON, 1981, p. 188).

Em suma, experiência significa que as "estruturas objetivas" impactam na vida das pessoas e o papel de historiadores e sociólogos é compreender "o que estas estruturas fazem", como atuam e como as pessoas reagem em relação a isso. Portanto, antes de possuir instituiçôes e valores "conscientemente definidos como classe", as pessoas atuam em formas de classe. Thompson fugiu da tautologia que "classe" é igual à "relação com os meios de produção" e explicou as consequências das relaçôes sociais estruturadas em torno das classes sobre os agentes desprovidos dessa consciência. Essas relações sociais são "pré-condição" para que os agentes se organizem conscientemente como classe. Além disto, demonstra que o conflito e a luta nascem das relaçóes de produção, enquanto as formaçóes de classe dependem da experiência do conflito e da luta (WOOD, 1983, s.p., tradução nossa). ${ }^{15}$

A interpretação de Thompson se baseia no binômio: relação e processo. A localização das classes é feita por meio de relações. Os processos de formação de classe são impulsionados pelas relações de exploração, conflito e luta (WOOD, 1983).

Pensar a classe como "relação" significa observar dois tipos de relações: (1) entre as classes e (2) entre os membros de uma mesma classe. Ou seja, classe não é uma mera categoria de estratificação. Como qualquer teoria materialista afirmaria, as relações de produção fundamentam as relações de classe. Porém, as relações de produção são aquelas estabelecidas por pessoas unidas pelo processo de produção e os antagonismos entre produtores diretos e apropriadores do excedente. Mas, não se reduz relaçôes de classe às relaçôes de produção porque nem todos os membros potenciais das classes históricas são vinculados diretamente pelo processo de produção ou de apropriação. São as pessoas agrupadas em classes e não as classes que produzem ou apropriam (WOOD, 1983).

A "classe" não se refere simplesmente aos trabalhadores agrupados em uma unidade de produção e opostos a um explorador comum em uma unidade de apropriação. A classe implica uma conexão que se estende para além do processo de produção imediato e do nexo imediato de extração, uma conexão que se projeta através das unidades de produção e apropriação particulares. As conexões e oposiçôes contidas no processo de

\footnotetext{
15 Thompson não elaborou um “vocabulário teórico 'rigoroso' para expressar os efeitos das condições materiais sobre seres ativos e conscientes". Por isso, alguns críticos enxergam no conceito de experiência a expressão de seu "subjetivismo" e “idealismo" (WOOD, 1983, s.p., tradução nossa).
} 
produção são a base da classe, mas a relação entre pessoas que ocupam posições similares nas relações de produção não está diretamente relacionada ao processo de produção e apropriação (WOOD, 1983, s.p., tradução nossa).

Thompson reconhece este conceito como um "processo estruturado". Isto é, "há uma base estrutural na formação de classe", mas é preciso procurar, empiricamente por meio de análise histórica e sociológica, nas relações antagônicas de produção as formas particulares em que as pressões estruturais atuam na formação das classes. Por essa proposição, Thompson foi acusado de equiparar "a classe com a consciência de classe". Entretanto, ele compreende que "as formas de consciência são moldadas em diversos modos pelas 'pressões determinantes' de situaçôes objetivas de classe", mesmo quando ainda não está expressa "uma identidade de classe autoconsciente e ativa". E entre uma situação objetiva, sem identidade autoconsciente, e uma formação visível de classe, consciente e ativa, está o "processo" histórico (WOOD, 1983, s.p., tradução nossa).

Quatro elementos são fundamentais para compreender a formação de classe em Thompson: (1) os trabalhadores participam ativa e conscientemente na formação de classe; (2) a classe formou a si própria tanto quanto foi formada, pois "as motivaçóes objetivas e subjetivas que levaram os trabalhadores a formar a classe operária não existiam teleologicamente"; (3) a classe acontece como resultados de experiências comuns que são herdadas ou compartilhadas, que permite aos homens sentir e articular seus "interesses entre si e contra os outros", cujos interesses são opostos; e (4) só é identificável quando o processo ocorre "durante um longo espaço de tempo e durante os quais se materialize culturalmente sua ideologia" (VITORINO, 1997/1998, p. 160-165).

Para Thompson (1978, apud WOOD, 1983, s.p., tradução nossa), ao compartilhar uma experiencia comum, "as classes surgem ou 'acontecem' porque as pessoas 'em relações determinantes produtivas' [...] identificam seus interesses comuns e passam a pensar e valorar em formas de classe". Quer dizer, o "ser social” e a "consciência social" são mediados pela experiência e não existem fora dela.

Segundo Vitorino, "ser social e consciência social existem porque são “experiencializados”". A experiência de classe remete a algo que os indivíduos realizam "enquanto produzem a riqueza material" no capitalismo. Deste modo, a "experiência" se torna "experiência de classe" quando faz a mediação das relações de produção e consciência social. Porém, a experiência nasce determinada pela reflexão que os 
indivíduos fazem ao que vivenciam, mas isto não significa que a consciência de classe nascerá sempre da mesma forma. Significa que o "ser social" não "determina direta, imanente e auto produtiva[mente]" a "consciência social" (VITORINO, 1997/1998, p. 168-170, grifos nossos).

Para isso fazer sentido à luz do marxismo, é preciso problematizar a metáfora do edifício para análise da "base" e da "superestrutura". Tal metáfora, segundo Wood, "gerou mais problemas do que soluçôes". Esse descompasso se agravou "pela tendência de Engels de usar uma linguagem que sugeria compartimentação de esferas ou 'níveis' fechados" e, também, "com o estabelecimento das ortodoxias stalinistas que elevaram - ou reduziram - a metáfora à condição de primeiro princípio do dogma marxista-leninista". Deste modo, tais "deformaçóes das ideias históricomaterialistas originais de Marx fixaram os termos do debate marxista desde então". Porém, o próprio Marx a utilizou "muito raramente e apenas nas formas mais aforísticas e alusivas” (WOOD, 2011b, p. 51).

Voltando à questão. Thompson (1987, p. 10), coerente com Marx, afirma que "a consciência de classe surge da mesma forma em tempos e lugares diferentes, mas nunca exatamente da mesma forma". Afinal, os homens não "escolhem as circunstâncias sob as quais ela [a história] é feita, mas estas lhe foram transmitidas assim como se encontram" (MARX, 2011, p. 25).

Ou seja, as relações objetivas de produção vão sempre importar, resultando ou não em uma consciência de classe bem definida, a questão é que importam "de formas diferentes em distintos contextos históricos". Isto quer dizer que as formações de classes são produzidas pelas relações objetivas de produção, como resultado de um processo histórico. Para Wood, o esforço de Thompson foi formular uma concepção de classe considere "como, e de que modos diferentes importam as situaçóes objetivas de classe" (WOOD, 1983, s.p., tradução nossa).

Portanto, Thompson não sucumbe a um "socialismo populista simplista". Afirmar o potencial revolucionário da cultura popular e a importância da experiência náo significa recusar a política organizada. Significa dizer que nenhuma política imposta "de cima" pode consolidar uma ideologia realmente revolucionária. E que a organização da classe trabalhadora para a luta deve partir da reflexão dos produtores sobre as relaçóes de produção, que pode ser estimulada, mas nunca substituída por manuais. Isto é, o trabalhador é o agente e não uma ferramenta revolucionária. Essa ressalva embasa a proposição da Democracia Substantiva, pois, nenhum regime que pretende a efetiva participação popular pode se fundar na descrença em relação à 
capacidade de discernimento da maioria trabalhadora (WOOD, 1983, 1998 e 2011b).

\title{
A questão das identidades sociais
}

Ellen Wood reconhece que "as pessoas têm outras identidades sociais, além da classe" e essas identidades "têm grande capacidade para dar forma às suas experiências". Porém, essa constatação seria um "truísmo" que não fornece conhecimentos necessários para um programa de emancipação. Por isso, seria preciso ampliar o conhecimento sobre "o que essas identidades significam, não apenas o que revelam sobre a experiência das pessoas, mas também o que ocultam" (WOOD, 2011b, p. 240). Resumidamente,

\begin{abstract}
[...] a indiferença estrutural do capitalismo pelas identidades sociais das pessoas que explora torna-o capaz de prescindir das desigualdades e opressóes extraeconômicas. Isso quer dizer que, embora o capitalismo não seja capaz de garantir a emancipação da opressão de gênero ou raça, a conquista dessa emancipação também não garante a erradicação do capitalismo. Ao mesmo tempo, essa mesma indiferença pelas identidades extraeconômicas torna particularmente eficaz e flexível o seu uso como cobertura ideológica pelo capitalismo (WOOD, 2011b, p. 241).
\end{abstract}

Wood percebe que recentemente houve uma redistribuição sem precedentes e uma correspondente desvalorização dos bens extraeconômicos - por exemplo, as liberdades civis e os direitos políticos. Ela não nega o avanço na ampliação das liberdades civis, dos direitos políticos, da igualdade jurídica e da cidadania do trabalhador, mas sua teoria objetiva a "reintegração da 'economia' à vida política da comunidade, que se inicia pela sua subordinação à autodeterminação democrática dos próprios produtores". Pois, a redistribuição desses bens extraeconômicos dissimula "as relações ocultas de desigualdade econômica, ausência de liberdade e exploração” (WOOD, 2011b, p. 241-242).

Por isso, a luta de classes deve estar no centro do projeto emancipatório com a classe trabalhadora enfrentando a "obscuridade da relação entre capital e trabalho" na apropriação da mais-valia, o "fetichismo da mercadoria [...] que dá às relações entre as pessoas a aparência de relações entre coisas" e a "mistificação política de que igualdade cívica significa não haver classe dominante". Para Wood (2011b, p. 241242), o êxito da classe trabalhadora: (1) eliminará as "necessidades ideológicas e econômicas que, sob o capitalismo ainda são atendidas pela opressão de raça e 
gênero"; e (2) "vai permitir a revalorização dos bens extraeconômicos, cujo valor foi deteriorado pela economia capitalista".

Entretanto, há questionamentos a serem enfrentados. Por um lado, é preciso reconhecer a importância da pluralidade de identidades sociais e, por outro, avaliar o quanto isso impacta na forma como o trabalhador "vivencia" e "apreende" sua situação de classe. Afinal, ao incorporar o conceito de classe de Thompson, a questão da "experiência" é central para que pessoas em uma "dada situação de classe" se agrupem em "formações conscientes de classe" (SARTELLI, 2013; THOMPSON, 1981 e 1987; WOOD, 1983, 1998 e 2011b).

Assim, se entre uma situação de classe e uma formação de classe plenamente desenvolvida temos a "experiência", em que os sujeitos racionais processam o que vivenciam ao longo do processo histórico, ficam as seguintes questões:

1) Se, para Wood, o capitalismo se aproveita das desigualdades culturais e políticas dos diferentes grupos identitários, ainda que essas desigualdades não sejam os principais sustentáculos do sistema, como desconsiderar que a situação de classe é experimentada de forma diferente em cada grupo identitário discriminado? Ou seja, grupos identitários diferentes não são submetidos a distintas formas de socialização e diferentes graus de exploração?

2) Isso não teria impacto na forma de refletir a experiência da situação de classe?

As consequências da sujeição étnico-racial ou de gênero antecedem à consolidação do capitalismo. Por um lado, o capitalismo se aproveita das imposições culturais e históricas para se desenvolver, por outro, as liberdades civis e os direitos políticos possibilitaram a reflexão sobre a impertinência destas situações.

Ellen Wood reconheceu que a pluralidade de identidades sociais impacta na "experiência" sem esclarecer as consequências sobre a possibilidade de "formações conscientes de classe" - que seria o agente para superar uma democracia capitalista esvaziada de conteúdo (WOOD, 2011b).

Por outro lado, Nancy Fraser (2009, p. 30) argumenta que "há uma afinidade eletiva e subterrânea entre o feminismo e o neoliberalismo"16, que:

[...] se encontra na crítica da autoridade tradicional. Tal autoridade é um alvo do ativismo feminista existente há muito tempo, que buscou, pelo menos desde Mary Wollstonecraft, emancipar as mulheres da sujeição

\footnotetext{
${ }^{16}$ Como esforço de "recalibragem" teórica é importante considerar o conjunto de ideias que impacta na atual etapa de acumulação capitalista e suas consequências sobre a organização do Estado.
} 
personalizada aos homens, sejam eles os pais, irmãos, padres, anciōes ou maridos. Mas a autoridade tradicional também aparece em alguns períodos como um obstáculo à expansão capitalista, parte do conteúdo social circundante em que os mercados historicamente foram incorporados e que serviu para delimitar a racionalidade econômica dentro de uma esfera limitada. No momento atual, estas duas críticas à autoridade tradicional, a feminista e a outra neoliberal, parecem convergir (FRASER, 2009, p. 30).

Segundo Fraser, há também uma decisiva divergência entre o feminismo e o neoliberalismo: a questão das formas "pós-tradicionais de subordinação de gênero" ${ }^{17}$. Isso significa que a "responsabilidade tradicional das mulheres para o processo de criar e educar os filhos ajuda a moldar os mercados de trabalho que as desfavorecem". Ou seja, o casamento provocaria "um ciclo de vulnerabilidade assimétrica [...] [que acarreta] poder desigual no mercado econômico, o que, por sua vez, reforça e exacerba o poder desigual na família". Porém, "tais processos de subordinação mediados pelo mercado são a própria essência do capitalismo neoliberal” e este deve ser o foco da crítica feminista na busca por se "distinguir do neoliberalismo e evitar a ressignificação feita por ele” (FRASER, 2009, p. 30).

Nesse ponto, a análise de Fraser converge com a constatação de Wood de que o capitalismo em tempos de acumulação flexível introduz uma concepção de mundo fragmentária e consegue cooptar as lutas identitárias, que podem, inclusive, contribuir, em momentos específicos, para a expansão capitalista, sem efetivamente garantir a emancipação das identidades sociais exploradas (FRASER, 2009; WOOD, 2011b). É o mercado econômico capitalista, em última instância, que instrumentaliza e potencializa a sujeição das diferentes identidades historicamente discriminadas. Fraser reafirma a necessidade da "luta contra a autoridade masculina tradicional", porém, isso deve ocorrer "reconectando as lutas contra a sujeição personalizada 'à crítica a um sistema capitalista', o qual [...] substitui um modo de dominação por outro" (FRASER, 2009, p. 30, grifo nosso).

Fraser propóe integrar o movimento feminista a uma luta sistêmica:

\footnotetext{
${ }^{17}$ Fraser (2009, p. 30) define "formas tradicionais de subordinação de gênero" como: "coaçôes na vida das mulheres que não adotam a forma de sujeição personalizada, mas surgem de processos estruturais ou sistêmicos nos quais as açôes de muitas pessoas são mediadas de forma abstrata ou impessoal”.
} 
[...] a tarefa é romper a identificação exclusiva da democracia com a comunidade política delimitada. Juntando outras forças progressistas, as feministas poderiam militar por uma nova ordem política pósWestfaliana - uma ordem escalar múltipla que é democrática em todos os níveis [...] a nova constelação de poderes democráticos deve ser capaz de retificar as injustiças em todas as dimensóes, ao longo de todos os eixos em todas as escalas. Tendo observado como o violento ataque neoliberal instrumentalizou nossas melhores ideias, temos uma abertura agora para reivindicá-las [...] poderíamos simplesmente dobrar o arco da transformação iminente na direção da justiça - e não apenas no que diz respeito a gênero (FRASER, 2009, p. 31-32).

Apesar de Fraser ser de uma filiação teórica cujo apego à esfera "discursiva" foi criticado por Wood, elas convergem quanto ao desejo de uma democracia que enfrente a dominação econômica. Segundo Fraser (2009, p. 31, grifo nosso), a "democracia participativa que buscamos hoje é uma que 'usa a política para domesticar os mercados' e guiar a sociedade no interesse da justiça” ${ }^{18}$. Portanto, são autoras teoricamente distintas, mas o que Fraser aponta, sobre o feminismo, pode contribuir para uma renovação do materialismo histórico.

Uma hipotética abolição das sujeições das diferentes identidades não significaria automaticamente a instauração da Democracia Substantiva. Por isso, deve ser alvo de detida reflexão a constatação de que o desafio é unificar a experiência em uma dada situação de classe, é fazer emergir o elo que unifica a experiência de diferentes identidades sociais no mundo do trabalho (FRASER, 2009; WOOD, $2011 b)^{19}$.

Portanto, mais do que refletir sobre "como essas identidades deveriam ser representadas na construção de uma política socialista”, é imperioso elaborar teoricamente para que as organizações políticas formule um plano de ação em que,

${ }^{18}$ É importante ressaltar que, para Ellen Wood, o mercado não é uma especificidade do capitalismo. Porém, em formaçóes pré-capitalistas os mercados não "moldaram a produção" (CALLINICOS, 2016). O que, portanto, aproxima a passagem de Fraser é a proposição de uma democracia onde o elemento político tenha vitalidade para limitar e definir o mercado e seu alcance. E isso significa, em última instância, a própria superação do cerne do capitalismo, para Ellen Wood, que é a separação entre o econômico e o político.

${ }^{19}$ Uma passagem importante nesse sentido é: "Certos instrumentos e instituiçóes hoje associados ao 'mercado' seriam, sem dúvida, úteis numa sociedade realmente democrática, mas a força motora da economia teria de emanar não do mercado, mas dentro da associação autoativa dos produtores" (WOOD, 2011b, p. 249). 
mesmo diante da fragmentação social, a situação de classe possa ser 'experiencializada" como algo comum a distintas identidades sociais (WOOD, 2011b, p. 240). Diferente de considerar diversas demandas específicas, a proposta é construir um programa de unidade da classe trabalhadora cujo diálogo entre as diferentes identidades focalize superar a exploração de classe.

Wood argumenta que a superação do capitalismo eliminará as "necessidades ideológicas e econômicas que sob o capitalismo ainda são atendidas pela opressão de raça e gênero" (WOOD, 2011b, p. 242). Porém, antes disto, como fazer com que as pessoas lutem para a superação da exploraçáo de classe? Se reconhecer a pluralidade das identidades sociais não fornece nenhum conhecimento satisfatório para um programa de emancipação, como convencer indivíduos conscientes com experiências díspares que a situação de classe é um elo? Afinal, o desafio é demonstrar a todos que a situação de classe fundamenta a exploração dos produtores e as demais identidades podem ser instrumentalizadas para aprofundar a exploração, mas não são o fundamento da exploração capitalista.

Wood retornou à Marx para enfrentar a "recessão" do marxismo, sustentou a validade do marxismo para pensar a totalidade sistêmica do capitalismo e argumentou que uma série de propostas ditas "pós-marxistas", no afã de compreender as mudanças do fim da Guerra Fria, reafirmaram as visões fragmentárias de mundo.

O limite permanece na necessidade de "substanciais recalibragens das leituras tradicionais” do pensamento de Marx e Engels (HOBSBAWM, 2011, p. 356). Isso inclui compreender como se expressa a multiplicidade de identidades sociais e como, apesar dessa multiplicidade, unificar a experiência para formação consciente de classe capaz de enfrentar o capitalismo como totalidade sistêmica (HOBSBAWM, 2011; WOOD, 2011b). Afinal:

É mais do que sabido, no marxismo, que os pensadores não inventam suas ideias em abstrato, mas só podem ser compreendidos no contexto histórico e político de seu tempo. Se Marx sempre frisou que os homens faziam sua própria história - ou, se alguém assim preferir, que pensam suas próprias ideias -, também ressaltou que eles só podem fazê-lo (para citar uma passagem famosa de $O 18$ de Brumário) nas condições em que se encontram imediatamente, em condiçóes que são legadas e herdadas do passado (HOBSBAWM, 2011, p. 287). 
Isso significa que os escritos de Marx "não formam um corpus acabado, mas são, como toda reflexão que merece esse nome, um interminável trabalho em curso" (HOBSBAWM, 2011, p. 22). Wood resgatou a obra marxiana e seguiu o curso do desenvolvimento do marxismo em um cenário adverso. Porém, como a história também é um contínuo movimento, há lacunas a serem desenvolvidas.

\section{As desigualdades e a dependência no capitalismo ocidental}

Sobre Marx, Hobsbawm (2011, p. 22) afirma: "ninguém mais vai transformálo em dogma e muito menos numa ortodoxia protegida por instituiçóes. Isso certamente teria chocado o próprio Marx". Assim como, provavelmente, chocaria Ellen Wood - e qualquer outro teórico consistente do materialismo histórico - se seu esforço de renovação fosse dado como algo acabado, dogmático ou livresco diante de uma história em constante mudança.

Nesse sentido, "qualquer conjunto de ideias sobrevive a seu criador [...] e está sujeito, na prática, a uma gama ampla de mudanças e transformaçóes, gama essa que se torna amplíssima na teoria", ou seja, "qualquer conjunto de ideias, inclusive as de Marx, transforma-se, necessariamente ao se tornar importante força política que mobilize massas, seja isso feito por meio de partidos e movimentos, de governos ou de outras formas", bem como um conjunto de ideias também se transforma conforme circula no espaço e no tempo (HOBSBAWM, 2011, p. 312-313).

Registrar a questão da historicidade do pensamento e da teoria faz sentido na medida em que a oposição fundamental entre burguesia e proletariado não se verifica com clareza em todo e qualquer tempo e lugar ${ }^{20}$. Ao registrar a necessidade de pensar a classe como relação e processo, a autora reafirma o compromisso com a historicidade. Além disto, a utilização dos termos "produtores", para se referir aos trabalhadores, e "apropriadores", para se referir à burguesia, abre um caminho para o reconhecimento da diversidade de situações possíveis e presentes no mundo do trabalho atual. Porém, ainda assim, é preciso ser mais específico. Como se trata de uma autora cuja produção foi interrompida - ou prejudicada - em função de graves problemas de saúde, é possível argumentar que há muito a ser desenvolvido a partir de suas linhas mestras para construir, de fato, uma teoria política. Uma das questóes a ser apontada é que Wood faz menção sempre ao "Ocidente capitalista". Afinal de contas, a autora entende que "o impulso em direção à democracia é uma motivação

\footnotetext{
${ }^{20}$ Gramsci foi pioneiro nessa constatação.
} 
comum" que une a onda de "anticapitalismos" e a democracia é a forma política mais disseminada no Ocidente (WOOD, 2011b, p. 7).

Todavia, é preciso registrar a desigualdade no desenvolvimento do capitalismo, mesmo no Ocidente. A partir disso é fundamental desenvolver a obra de Wood no sentido de refletir como, de fato, tornar a democracia uma motivação, mesmo nas áreas mais pobres e precárias do capitalismo, onde a ordem do dia é a sobrevivência. $\mathrm{Na}$ periferia do capitalismo há relaçôes de trabalho que, à primeira vista, podem ser chamadas de "pré-capitalistas" - como o trabalho análogo à escravidão, arrendamentos, exploraçáo do trabalho informal, etc. -, mas que, em última instância, denunciam o caráter da superexploração capitalista ${ }^{21}$.

Cada vez mais, tais características da "periferia" adentram o centro capitalista. Assim, a pergunta que se impóe é: como unificar a experiência de exploração de grupos que vivenciam relaçôes de trabalho tão distintas? Gunder Frank (2005 e 2016) deu sua contribuição propondo a tática da "guerra de guerrilhas" iniciada no plano local e nacional, sobretudo para enfrentar a produção dos elementos simbólicos e a difusão da informação. Porém, persiste a necessidade de desenvolvimento: será possível uma formação consciente de produtores que vivem realidades tão distintas? Ou teríamos diferentes grupos subalternos enfrentando pontualmente a exploração sofrida? Por fim, qual o programa para que isso ocorra? ${ }^{22}$

Considerar essas questóes é reconhecer que:

[...] o que deu errado não foi a predição do Manifesto quanto ao papel central dos movimentos políticos baseados na classe operária (e que ainda, às vezes, ostentam o nome da classe, como os Partidos Trabalhistas da Grã-Bretanha, Holanda, Noruega e Australásia). Foi a afirmação de que 'de todas as classes que hoje confrontam a burguesia, apenas o proletariado é uma classe verdadeiramente revolucionária’, uma classe

\footnotetext{
${ }^{21}$ Sobre a Teoria da Dependência, ler Rui Mauro Marini (1991, 2008 e 2017) e conhecer a lei do desenvolvimento desigual e combinado, que embasa a elaboração da Teoria da Dependência. Comumente associada à Trotsky, essa lei foi aprofundada por George Novack. Cf. Demier (2007) e Löwy (1998).

${ }^{22}$ Gunder Frank $(2005$; 2016) aponta indicativos valiosos, sobretudo, a tese da "guerra de guerrilhas". É mais provável a obtenção da mobilização popular para enfrentar a burguesia nacional, do que mobilizar para luta anti-imperialista. Além disso, combater a burguesia nacional também tem eficácia no combate político-ideológico, afinal "A burguesia da metrópole nacional colabora com o imperialismo no contexto da exploração colonial e da exploração de classe do seu próprio povo" (GUNDER FRANK, 2016, p. 395-398).
} 
cujo destino inevitável, implícito na natureza e no desenvolvimento do capitalismo, é derrubar a burguesia: 'Sua queda e a vitória do proletariado são igualmente inevitáveis’ (HOBSBAWN, 2011, p. 110).

\section{Considerações Finais}

Para este trabalho, consideramos fundamentais quatro constataçóes de Ellen Wood para a renovação do materialismo histórico: (1) a necessidade de repensar a relação "base" e "superestrutura", superando ortodoxias que sugerem um determinismo econômico; (2) até o momento, nas sociedades capitalistas mais desenvolvidas, a militância tendeu a surgir em resposta a uma compulsão extraeconômica - ações opressivas do Estado - e variou proporcionalmente ao envolvimento do Estado em torno dos termos e das condiçóes do trabalho; (3) a partir da fundação dos Estados Unidos, o conceito de democracia passou a ser atrelado a uma noção de cidadania em que o poder puramente "econômico" substituiu o privilégio político; e (4) a insuficiência - e não a frivolidade - dos Partidos e dos intelectuais e para conduzir os trabalhadores a uma "formação consciente de classe". Por isso, é fundamental o entendimento das especificidades históricas e do reflexo da mudança de arena e dos objetivos da luta política inerente à própria estrutura da produção capitalista (WOOD, 1983, 1998 e 2011b).

Desse modo, o desafio de Wood ainda está de pé: reinserir, na agenda da teoria, categorias de análises que ajudem a compreender o momento da luta política e econômica atual. A luta de classes como motor da história não é um conceito superado, mas, para compreender como as classes lutam, a transposição de conceitos que serviram em outros contextos é insuficiente.

É mais que sabido, no marxismo, que os pensadores não inventam suas ideias em abstrato, mas só podem ser compreendidos no contexto histórico e político do seu tempo. Se Marx sempre frisou que os homens faziam sua própria história - ou, se alguém assim preferir, que pensam suas próprias ideias -, também ressaltou que eles só podem fazê-lo (para citar uma passagem famosa de $\mathrm{O} 18$ de Brumário) nas condições em que se encontram imediatamente, em condiçôes que são legadas e herdadas do passado (HOBSBAWM, 2011, p. 287). 
Entretanto, o esforço de Wood se deu em meio a um "marxismo em recessão", cujos sintomas são: (1) a "crise dos partidos comunistas europeus fora do poder e dos partidos e governos socialistas estava mais do que evidente"; (2) a regressão do marxismo entre os intelectuais, que fica evidente nos anos 1980; (3) a partir de 1974, nota-se "uma volta ao laissez-faire intransigente. Só no fim dos anos 1990 começaram a aparecer rachaduras nesse consenso predominante”; (4) nas ciências sociais e humanas o marxismo vai perdendo o papel central que ocupava, inclusive, metodologicamente; e (5) na própria antiga esquerda radical era perceptível um "recuo em relação ao marxismo" (HOBSBAWM, 2011, p. 349-353).

Em reação, Wood voltou aos textos marxianos e se tornou resistência no intento de sustentar a importância do materialismo histórico para enfrentar a totalidade sistêmica do capitalismo (SARTELLI, 2013; MONTENEGRO, 2012). A autora se tornou voz ativa e buscou recuperar o caráter histórico do marxismo por meio do Marxismo Político, realizando uma análise original a partir dos textos marxianos. Essa originalidade guarda relação com o que Hobsbawm (2011, p. 356) chama de "substanciais recalibragens das leituras tradicionais" do pensamento de Marx.

O contexto em que se tornam necessárias as "recalibragens" do marxismo é marcado por três conclusões desafiadoras:

1) Não é possível uma Democracia Substantiva, entendida como poder pelo demos, que garanta a isegoria, autodeterminação dos produtores e a "liberdade de livre associação" em uma sociedade capitalista, marcada pela separação entre o "político" e o "econômico". Afinal, alguns poderes políticos importantes que garantem a apropriação estão intocados na propriedade privada dos meios de produção. Então, o que chamamos hoje de democracia é um governo representativo em que a condiçáo de cidadania foi universalizada, mas é cada vez menos poderosa;

2) Também não é possível pensar em estratégias de desenvolvimento nacionais e autônomas nos quadros da dependência. A economia mundial é articulada em elos de dependência em que as metrópoles dependem da exploração de seus satélites. Assim, a tendência é o desenvolvimento das metrópoles e o subdesenvolvimento dos satélites. As áreas atrasadas não são entraves ao desenvolvimento capitalista e, sim, satélites explorados e/ou superexplorados que alimentam a dinâmica capitalista. Isto chama a atenção para a viabilidade da Democracia Substantiva no socialismo em um país 
periférico, ao mesmo tempo em que resgata a proposta de Gunder Frank de uma "guerra de guerrilhas", começando no enfrentamento da burguesia nacional;

3) Tanto a Democracia Substantiva, quanto a ruptura de uma situação de dependência dependem da luta de classes. E é aí que temos algumas questôes: de que classe estamos falando? As produções de clássicos do passado são suficientes para compreensáo da luta de classes hoje? Ou, se apenas fornecem subsídios, quais são as mediações necessárias e possíveis para pensar a luta de classes atualmente?

Wood propõe a renovação do materialismo histórico visando a Democracia Substantiva no socialismo. Essa renovação depende da retomada do espírito crítico do marxismo, da compreensão da centralidade da luta política para superação do capitalismo, e do abandono dos elementos particularistas da luta sócio-política contemporânea, o que demanda reflexão sobre o estágio atual da luta de classes e atualização das análises sobre o conceito de classe (WOOD, 2011b).

A Democracia Substantiva, o norte da proposição de Wood, é a organização político-social capaz de enfrentar a exploração de classe e de tornar inócuos os fundamentos que subjugam as identidades sociais histórica e culturalmente discriminadas para ampliar a capacidade de apropriação da classe dominante. Mais do que isso, a luta pela democracia permite a unificação das diversas manifestaçôes anticapitalistas. Nesse ínterim, as liberdades civis básicas são indispensáveis. Porém, para além dessas liberdades, é preciso recuperar integralmente a concepção de governo pelo povo ou pelo poder do povo.

Isto implica que o demos, o homem comum, tenha condições de enfrentar a dominação de classe. Qualquer projeto que acredita na reforma da democracia e sua compatibilidade com o capitalismo, é "menos anticapitalista que antineoliberal ou antiglobalização". Pois, os imperativos do mercado têm primazia sobre a vontade e as necessidades do povo impossibilitando "um capitalismo governado pelo poder popular" (WOOD, 2011b, p. 7-8). Ou seja, "um capitalismo humano, 'social' e verdadeiramente democrático e igualitário é mais irreal e utópico que o socialismo" (WOOD, 2011b, p. 250).

A democracia pensada por Wood só é possível a partir do resgate da centralidade da luta de classes e funciona como "um regulador econômico, o mecanismo acionador da economia" para garantir a liberdade de livre associação e, por consequência, "a emancipação de coaçóes 'econômicas'." Afinal, não basta a "reapropriação dos meios de produção pelos produtores [...] [quando a] posse 
permanece dependente do mercado e dos velhos imperativos" (WOOD, 2011b, p. 248).

Por essa linha, pensar as possibilidades de uma Democracia Substantiva é teorizar modos de garantir aos produtores a capacidade de autodeterminação. E, para isso, é necessário que os apropriadores sejam despossuídos dos poderes de extração que, apesar de incluir poderes políticos, estấo intocados no "econômico", logo, fora do alcance do Estado e de qualquer possibilidade de enfrentamento nos limites da democracia liberal.

A proposta analítica para essa renovação é a compreensão da classe como relação e processo como caminho necessário para superar os elementos particularistas da luta social e política. Afinal, não se enfrenta a separação entre o "político" e "econômico" sem a unificação na experiência e na consciência de acontecimentos díspares e aparentemente desconectados ou, dito de outro modo, sem que a classe seja "algo que ocorre efetivamente (e cuja ocorrência possa ser demonstrada) nas relações humanas" (THOMPSON, 1987, p. 9).

Enquanto houver proprietários e não proprietários, produtores e apropriadores haverá luta de classes. O desafio é compreender o que acontece entre uma "situação de classe", determinada pelas relações de produção, e a existência de "formações conscientes de classe". Tal desafio mobilizou Thompson e, segundo avaliação de Wood, os esforços do historiador legaram as bases para uma teoria de classes, baseada no binômio "processo" e "relação".

- Jefferson Ferreira Nascimento é Doutorando em Ciência Política, pela Universidade Federal de São Carlos (UFSCar). Membro do Núcleo de Estudos dos Partidos Políticos Latino Americanos (NEPPLA ) e Professor no Instituto Federal de Educação, Ciência e Tecnologia de São Paulo (IFSP) - Campus Sertãozinho. E-mail: jefferson.nascimento@ifsp.edu.br. 


\section{Referências}

BRANDÃO, Gildo M. A Teoria Política é possível? Revista Brasileira de Ciências Sociais, v. 13, n. 36, 1998. Disponível em: <http://www.scielo.br/pdf/rbcsoc/v13n36/36gildo.pdfs. Acesso em: 16 nov. 2018.

CALLINICOS, Alex. Marxism loses a passionate champion. Socialist Review, n. 410, Fev. 2016. Disponível em: <http://socialistreview.org.uk/410/marxism-loses-passionate-champion>. Acesso em: 24 mar. 2017.

DEMIER, Felipe. A lei do desenvolvimento desigual e combinado de León Trotsky e a intelectualidade brasileira: breves comentários sobre uma relação pouco conhecida. COLÓQUIO DO CENTRO DE ESTUDOS MARXISTAS, CEMARX , v. 6-9 nov. 2007, Anais... Campinas: UNICAMP, IFCH, $2007 . \quad$ Disponível em: <http://www.unicamp.br/cemarx/anais_v_coloquio_arquivos/arquivos/comunicacoes/gt3/sessao3/Fe lipe_Demier.pdf $>$. Acesso em: 09 nov. 2018.

FRASER, Nancy. O Feminismo, o Capitalismo e a astúcia da História. Revista Mediaçóes, Londrina, v. 14, n. 2, p. 11-33, 2009.

GUNDER FRANK, André. Capitalismo y subdesarrollo en América Latina. CEME - Centro de Estudios Miguel Enriquez. Chile, 2005. Edição Eletrônica. Disponível em: $<$ http://www.archivochile.cl/Ideas_Autores/gunderfa/gunderfa0006.pdf >. Acesso em: 15. nov. 2018.

O inimigo imediato. In: LÖWY, Michael (Org.). O Marxismo na América Latina: uma antologia de 1909 aos dias atuais. São Paulo: Expressão Popular: Perseu Abramo, 2016. p. 394-399.

HOBSBAWM, Eric J. Como mudar o mundo: Marx e o marxismo, 1840-2011. São Paulo: Companhia das Letras, 2011.

LÖWY, Michael. A teoria do desenvolvimento desigual e combinado. Outubro, São Paulo, n. 01, p. 73-80, 1998.

MARINI, Ruy Mauro. Dialéctica de la dependência. Ciudad de México: Ediciones Era, 1991. América Latina, dependencia y globalización. Compilador Carlos Eduardo Martins. Bogotá: CLACSO y Siglo del Hombre Editores, 2008 Subdesenvolvimento e Revolução. Florianópolis: Editora Insular, 2017.

MARX, Karl. O dezoito de brumário de Luís Bonaparte. São Paulo: Boitempo, 2011.

. O capital: crítica da economia política: Livro III: o processo global de produção capitalista. São Paulo: Boitempo, 2017.

MONTENEGRO, Darlan. A separação entre o econômico e o político e a questão da democracia no pensamento de Ellen M. Wood. 2012. Revista Crítica Marxista, Campinas, n. 34, p. 111-124, 2012. SANTANA, Marco A.; RAMALHO, José R. Sociologia do Trabalho no Mundo Contemporâneo. 3. ed. Rio de Janeiro: Jorge Zahar Ed. 2010.

SARTELLI, Eduardo. La Niebla. In: WOOD, Ellen. ¿Una Política sin Clases? El post-marxismo y su legado. Buenos Aires: RyR, 2013. p. 7-24.

THOMPSON, Edward Palmer. A Miséria da Teoria ou um planetário de erros - uma crítica ao pensamento de Althusser. Rio de Janeiro: Zahar Editores, 1981.

A Formação da Classe Operária Inglesa - volume I: A árvore da liberdade. Rio de Janeiro: Paz e Terra, 1987.

VITORINO, Arthur J. R. Notas sobre a teoria de formação de classe de E. P. Thompson. História Social, Campinas, n. 4-5, p. 157-173, 1997/1998. 
WOOD, Ellen M. El concepto de clase en E. P. Thompson. Cuadernos Políticos, México, n. 36, p. 87-105, México D.F.: Ediciones Era, abr-jun. 1983. Disponível em: <http://www.cuadernospoliticos.unam.mx/cuadernos/contenido/CP.36/CP.36.9.EllenMeiksinsWoo d.pdf>. Acesso em: 15 nov. 2018.

. The Retreat from Class: a new 'true' Socialism. London/New York: Verso, 1998.

. De ciudadanos a señores feudales - História social del pensamiento político desde la Antigüedad a la Edad Media. Barcelona, Buenos Aires, México: Paidós, 2011 a.

- Democracia contra o capitalismo: a renovação do materialismo histórico. São Paulo:

Boitempo, 2011b.

WOOD, Neal. Reflections on Political Theory: a voice of reason from the past. New York: Palgrave, 2002.

Texto recebido em 31 de dezembro de 2018.

Aprovado em 11 de março de 2019. 